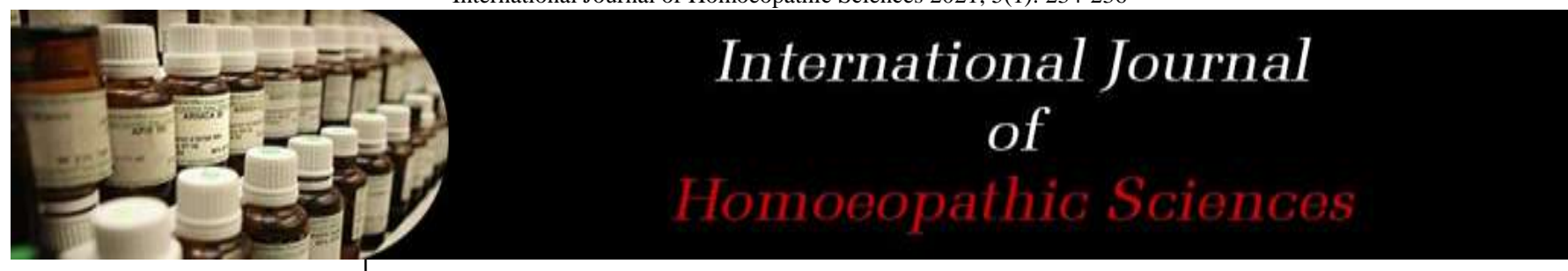

E-ISSN: $2616-4493$ P-ISSN: 2616-4485 www.homoeopathicjournal.com IJHS 2021; 5(1): 234-236 Received: 25-11-2020 Accepted: 06-01-2021

Dr. Subhash Chand Yadav Professor, PG Guide, Department Of Repertory, Swasthya Kalyan

Homoeopathic Medical College \& Research Centre, Sitapura, Jaipur, Rajasthan, India

Dr. Anshuman Kankoriya M.D.(PGR), Department of Repertory, S. K.

Homoeopathic Medical College and Research Centre, Jaipur,

Rajasthan, India
Corresponding Author: Dr. Subhash Chand Yadav Professor, PG Guide, Department Of Repertory, Swasthya Kalyan Homoeopathic Medical College \& Research Centre, Sitapura, Jaipur, Rajasthan, India

\section{Corn treated with homoeopathic medicine: A case study}

\section{Dr. Subhash Chand Yadav and Dr. Anshuman Kankoriya}

DOI: $\underline{\text { https://doi.org/10.33545/26164485.2021.v5.i1d.321 }}$

\section{Abstract}

Corn is a type of callosity which is caused by repeated friction of skin. Present especially on sole of foot and toes. It is manifested by pain on walking and standing. A 26 year male patient reported with complaints of corn with pain on right sole of foot. Case taking was done followed by repertorization using Synthesis 9.0 repertory Radar 10.0 and Sulphur has been given as an individualized medicine.

Keywords: Homoeopathy, Corn, RADAR, sulphur

\section{Introduction}

Corn is the type of callosity which is also known as a focal intractable planter hyperkeratosis. In this skin which is involve become thick which is caused by repeated mechanical trauma due to friction ${ }^{[1]}$.

Rubbing divides the epidermis and grow more than usual. Due to this skin become more thick $^{[2]}$

The corn most commonly present in athletes, older people and persons who are exposed to unequal friction force from footwear ${ }^{[1]}$.

It is most commonly present on tops and side of toes. It has two type hard and soft corn. Hard corn has thickened surface with packed center, where soft corn has thinner surface. Sometimes the patient may remain asymptomatic and sometimes become symptomatic with tenderness if it is present ${ }^{[3]}$.

It may be painful especially during walking and standing ${ }^{[2]}$.

\section{Case Study}

Mr. XY, 26 year, Male, lean thin, tall with fair complexion, Hindu, Unmarried, Vegetarian, doing Job in swiggy, attended the out-patient department of the Swasthya kalyan homoeopathic medical college and research centre, sitapura, Jaipur (Rajasthan) present himself with the known case of corn on 06/07/2020, on further enquiry he told that complaint had started gradually since 6 months, two month after death of his father due to cardiac arrest. Complaining of pain and burning in sole of right foot. Pain aggravated during walking. He took alternative medicines orally and as an external application applies many ointments on corn but no relief.

Father died at the age of $52 \mathrm{yr}$ due to cardiac arrest, mother had a history of diabetes \& hypertension since 10 years/alive.

The mental general reflected sadness and silent grief after death of his father.

Regarding his past history the patient further reported that he had suffered from repeated attacks of tonsillitis which was cured of after taking alternative treatments.

He had strong desire for taking sweets and sour things.

He was addicted to chewing tobacco.

Perspiration profuse on axilla with sour odor.

Tongue - Red tip, moist.

Thermal - hot

\subsection{Analysis of case}

\subsubsection{Mental General}

- Complaint come after death of loved once.

- Grief silent 


\subsubsection{Physical general}

- Tongue-Tip of tongue red, moist.

- Desire - Sweets and sour things.

- Perspiration- Odor sour especially on axilla.

- Thermal - Hot.

\subsubsection{Particulars}

- Corn on sole of right foot.

- Corn painful, especially on walking.

- Corn burning.

\subsection{Evaluation}

- Complaint come after death of loved once.

- Grief silent.

- Tongue-Tip of tongue red, moist.

- Desire - Sweet and sour things.

- Perspiration- Odor, sour, especially on armpit.

- Corn on sole of right foot.

- Corn painful, especially on walking.

- Corn burning.

- Pain on corn especially walking.

- Thermal - Hot.

\subsection{Totality of symptoms}

- Complaint come after death of loved once.

- Grief silent.

- Corn on sole of right foot.

- Corn painful, especially on walking.

- Corn burning.

- Pain on corn especially walking.

- Tongue-Tip of tongue red.

- Perspiration- Odor, sour.

\subsection{Rubric}

Table 1: Rubric

\begin{tabular}{|c|c|c|}
\hline S. No. & Chapter & Rubric \\
\hline 1. & Mind & Ailments From - death of loved ones \\
\hline 2. & Mind & Grief - silent \\
\hline 3. & Mouth & Discoloration - Tongue - red - tip \\
\hline 4. & Extremities & Callosities - Foot - soles on \\
\hline 5. & Extremities & Corns - painful \\
\hline 6. & Extremities & Corns - burning \\
\hline 7. & Extremities & Pain - Foot - Sole - walking, while \\
\hline 8. & Perspiration & Odor - sour \\
\hline 9. & Generals & Side - right \\
\hline
\end{tabular}

\subsection{Repertorial Sheet ${ }^{[9]}$}

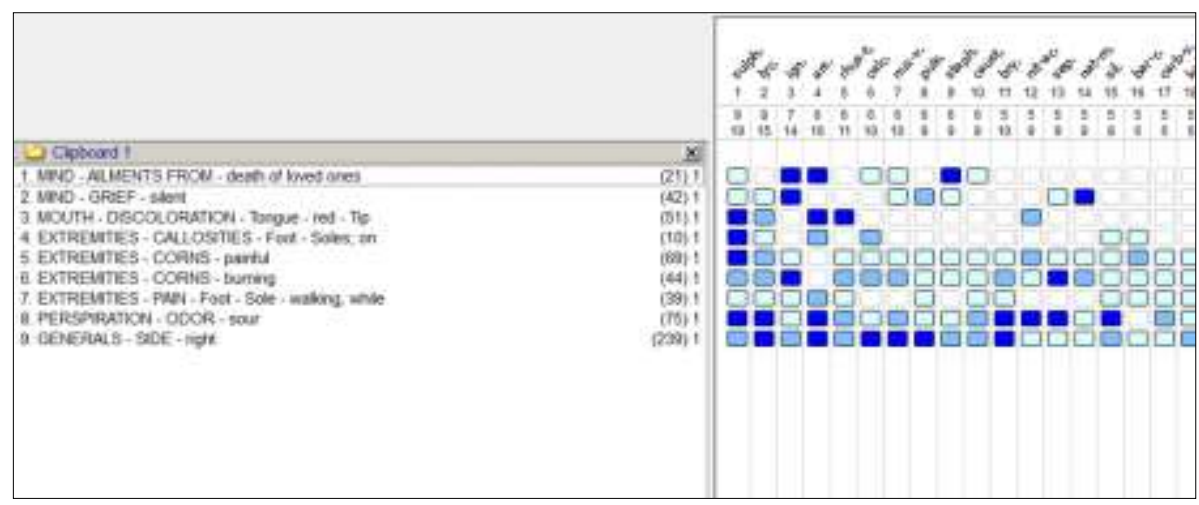

Fig 1: Showing repertorization of case from Synthesis 9.0 Repertory using Radar (Version 10.0)

\subsection{Analysis of Repertorial Result}

Table 2: Repertorial Result

\begin{tabular}{|c|c|c|}
\hline S. No. & Medicine & Mark Obtain \\
\hline 1. & Sulphur & $19 / 9$ \\
\hline 2. & Lycopodium clavatum & $15 / 8$ \\
\hline 3. & Ignatia amara & $14 / 7$ \\
\hline 4. & Arsenicum album & $16 / 6$ \\
\hline 5. & Rhus toxicodendron & $11 / 6$ \\
\hline
\end{tabular}

\subsection{Selection of medicine}

Sulphur seems to suit the case not only because it get highest marks during repertorization but also cover most of the symptoms of the case. Patient has marked mental symtoms like silent grief and complaint come after death of loved ones, desire for sweet and sour things and patient thermally hot.

\subsection{Prescription}

Table 3: Prescription

\begin{tabular}{|c|c|}
\hline Date & Prescription \\
\hline 06/07/2020 & Rx Sulph 200 1 Dose Stat \\
& Rubrum 30 TDS 6Hourly x 15 Days \\
\hline
\end{tabular}

\subsection{Followup Sheet}

Table 4: Followup Sheet

\begin{tabular}{|c|c|c|}
\hline Date & Symptoms & Prescription \\
\hline $21 / 07 / 2020$ & Status quo & Rx Rubrum 30 TDS 6 Hourly x 15 Days \\
\hline $5 / 08 / 2020$ & Improvement in pain and burning. & Rx Rubrum 30 TDS 6 Hourly x 15 Days \\
\hline $19 / 08 / 2020$ & Complaint is stand still. & Rx Sulph 200 1 Dose Stat Rubrum 30 TDS 6 Hourly x 15 Days \\
\hline $02 / 09 / 2020$ & No pain and burning. & Rx Rubrum 30 TDS 6 Hourly x 15 Days \\
\hline $17 / 09 / 2020$ & Decrease in size of corn. No pain and burning. & Rx Rubrum 30 TDS 6 Hourly x 10 Days \\
\hline
\end{tabular}




\begin{tabular}{|c|c|c|}
\hline $28 / 09 / 2020$ & Corn size is same, slight pain present. & Rx Sulph 1M 1 Dose Stat Rubrum 30 TDS 6 Hourly x 15 Days \\
\hline $12 / 10 / 2020$ & No pain & Rx Rubrum 30 TDS 6 Hourly x 15 Days \\
\hline $27 / 10 / 2020$ & Reduce in size of corn. There is no pain. & Rx Rubrum 30 TDS 6 Hourly x 30 Days \\
\hline $25 / 11 / 2020$ & No corn present. & Rx Rubrum 30 TDS 6 Hourly x 30 Days \\
\hline $26 / 12 / 2020$ & No complaint. Patient feel good. & Rx Rubrum 30 TDS 6 Hourly x 30 Days \\
\hline
\end{tabular}

\subsection{Picture}

\subsubsection{Before Treatment}

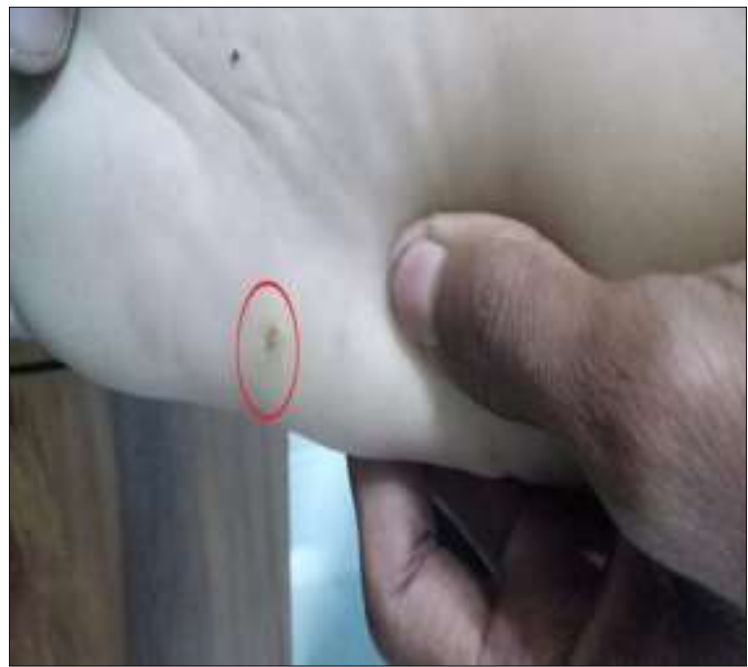

Fig 2: Before Treatment

\subsubsection{After Treatment}

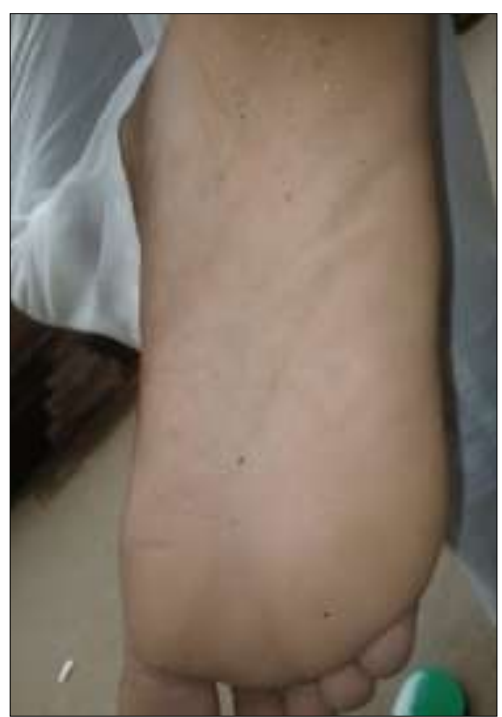

Fig 3: After Treatment

\section{Conclusion}

Homoeopathy have massive and beautiful work on the quality of life (Qol) of those who are suffering from Corns, homoeopathy has prove its effectiveness in such type of cases and so this case further proves the therapeutic value and strong power of homoeopathic medicines in cure of Corns.

\section{References}

1. Al Aboud AM, Yarrarapu SNS. Corns. Stat Pearls. Updated 2020, 25.

2. InformedHealth.org. Cologne, Germany: Institute for Quality and Efficiency in Health Care (IQWiG) 2006. Corns: Overview 2019, 11.
3. Gardner SS, Corns and calluses. WebMD. 2019, 26.

4. Dr. Ramanlal P. Patel: The Art of Case Taking and Practical Repertorisation in Homoeopathy, $5^{\text {th }}$ Edition, Pub.: Dr. J.R. Patel Hahnemann House, Kottayam (Kerala) 1990, 686001.

5. Dr. Samuel Hahnemann (B.K. Sarkar): Organon of Medicine, $5^{\text {th }} \& 6^{\text {th }}$ Edition, 1984, $8^{\text {th }}$ Indian Edition, Pub.: M. Bhattacharya \& Co. (p) Ltd., Calcutta-1.

6. Michael Swash. Hutchinson's Clinical Methods, $19^{\text {th }}$ Edition, 1990, P.: Funded by the British Government. Adi BS. Efficacy of homoeopathic medicines in chronic low back pain: A clinical study. International Journal of Alternative and Complementary Medicine 2020, 17-20. Indian dermatology online journal 2014;5(4):535.

7. Farrington EA, MD. Comparative Materia Medica 1986, Pub.: B. Jain Publishers Pvt. Ltd., New Delhi-110 055.

8. Clark JH. A Dictionary of Practical MateriaMedica. Delhi. B Jain. Publications 1, 2, 3, 2003.

9. Computer Repertory: RADAR (Version 10.0), Schroyens F, Synthesis 9.0 (English). 